\title{
Polymorphism in the promoter region of the mannose-binding lectin gene among human T-cell lymphotropic virus infected subjects
}

\author{
AEM Alves, RB Hermes, B Tamegão-Lopes*, LFA Machado, VN Azevedo, MOG Ishak, \\ R Ishak, JAR Lemos, ACR Vallinoto/ ${ }^{+}$
}

\begin{abstract}
Universidade Federal do Pará, Instituto de Ciências Biológicas, Laboratório de Virologia, Rua Augusto Corrêa s/n, Guamá, 66075-900 Belém, Pará, Brasil *Centro de Hematologia e Hemoterapia do Estado do Pará - HEMOPA, Belém, Pará, Brasil
\end{abstract}

The present study investigated the frequency of the mutations at positions -550 and -221 of the mannosebinding lectin (MBL) gene in a sample of 75 human T-cell lymphotropic virus (HTLV) infected patients and 96 HTLV seronegative controls, in order to evaluate the occurrence of a possible association between the polymorphism and HTLV infection. A sequence specific primer-polymerase chain reaction was used for discrimination of the polymorphism. The analysis of allele frequencies at position -550 did not show any significant differences between HTLV infected group and controls, but there was a significant difference at position -221. The comparative analysis of haplotypes frequencies were not significant, but the genotype frequencies between the two groups, revealed a higher prevalence of genotype LYLX (25.3\%), associated with medium and low MBL serum levels among HTLV infected subjects. The odds ratio estimation demonstrated that the presence of genotype LYLX was associated with an increased risk of HTLV infection $(p=0.0096 ; 1.38 \leq$ IC95\% $\leq 7.7605)$. There was no association between proviral load and the promoter polymorphism, but when promoter and exon 1 mutations were matched, it was possible to identify a significant higher proviral load among HTLV infected individuals carrying haplotypes correlated to low serum levels of $M B L$. The present study shows that the polymorphism in the promoter region of the MBL gene may be a genetic marker associated with HTLV infection, and emphasizes the need for further studies to determinate if the present polymorphism have any impact on diseases linked to HTLV infection.

Key words: mannose-binding lectin - genetic polymorphism - human T-cell lymphotropic virus

Mannose-binding lectin (MBL) is a liver-derived serum lectin with an important role in the host's innate immune system, which binds with high affinity to mannose or other carbohydrate components present on the surface of viruses, bacteria and yeasts (Turner 2003). The MBL is an acute-phase protein witch may mediate phagocytosis or activate the lectin pathway of complement (Kilpatrick 2002).

The identification of the mutation in the promoter region of the MBL gene showed that serum MBL concentration is also modulated in transcriptional levels (Madsen et al. 1995). Nucleotide substitutions in positions $-550(\mathrm{G}$ to $\mathrm{C})$ and $-221(\mathrm{G}$ to $\mathrm{C})$ provide the variants $H(G) / L(C)$ and $Y(G) / X(C)$, respectively. Several promoter variants which apparently do not alter the levels of MBL were described, but HY, LY and LX haplotypes are currently associated to high, medium and low levels of circulating MBL in the plasma, respectively (Madsen et al. 1995, Steffensen et al. 2000). MBL function is directly associated with its serum concentration which is determined by the interplay between promoter and structural gene mutations (Madsen et al. 1995, Jüliger et al. 2000).

Financial support: CNPq, Funtec/Sectam, Universidade Federal do Pará

${ }^{+}$Corresponding author: vallinoto@ufpa.br

Recieved 23 August 2007

Accepted 18 December 2007
Human T-cell lymphotropic virus 1 and 2 (HTLV-1 and HTLV-2) are members of the family Retroviridae and share several molecular and biological properties (Hall et al. 1994). HTLV-1 is endemic in diverse geographical regions and is associated with adult T-cell leukemia/lymphoma (ATLL) and a neurodegenerative disorder named tropical spastic paraparesis/myelophaty associated to HTLV-1 (TSP/HAM) (Gessain et al. 1985, Osame et al. 1986). The vast majority of HTLV-1-infected individuals remain asymptomatic, suggesting that HTLV-1 infection alone is not sufficient to cause HTLV-1-related diseases. Furthermore, until now it is unclear why certain individuals develop ATLL and others develop TSP/ HAM, but genetic factors seem to be important (Nishimura et al. 2000, 2003, Nitta et al. 2003)

Recently, we have shown a strong association between structural MBL gene mutations and the susceptibility and proviral load of HTLV-1 (Pontes et al. 2005). The present study investigated the association between polymorphism in the promoter region of the mannose-binding lectin gene and the susceptibility to HTLV infection.

\section{SUBJECTS, MATERIALS AND METHODS}

Subjects - A total of 75 blood samples from HTLV infected asymptomatic subjects (51 HTLV-1 and 24 HTLV-2; 46 males and 20 females, mean age 40 years), attended in the Blood Bank of the state of Pará (PA), Brazil (HEMOPA), which were enrolled in our previous studies concerned about exon 1 polymorphisms in the MBL gene (Pontes et al. 2005). Additionally, 99 HTLV seronegative subjects residing in Belém, capital of PA, were included in the present study as control group. 
Blood samples, from both HTLV infected patients and controls, were collected in Vacuntainer tubes containing $\mathrm{K}_{3}$-EDTA as anticoagulant in order to obtain plasma and peripheral blood mononuclear cells (PBMC) and screened for HTLV-1/2 antibodies using an enzymelinked immunosorbent assay (Ortho Diagnostic, Raritan, NJ, USA). Blood samples were directed to the Virus Laboratory (Institute of Biological Sciences, Federal University of Pará) to investigate the MBL gene polymorphisms. All subjects signed a thoroughly-explained consent form at the first visit.

$M B L$ genotyping - Genomic DNA was extracted from PBMC using the purification kit GFX for genomic DNA (Amersham Pharmacia Biotech, USA). Sequence specific primer-polymerase chain reaction (PCR) was used for discrimination of the polymorphism at -550 (316pb [H-550]/ [L-550]) and -221 (440pb [X-221] and 443pb [Y-221]) positions of the MBL gene promoter using a Mastercycler Personal termocycler (Eppendorf) following the protocol as previous reported (Steffensen et al. 2000).

Proviral load quantification - The quantification of HTLV proviral load was performed by a real-time PCR assay, as previous described (Tamegão-Lopes et al. 2006).

Statistical analysis - The statistical significance of the differences found between the allele and genotype frequencies were estimated by the $\chi^{2}$ test followed by Yates' correction. The association analysis between genetic polymorphism and the mean values of proviral load count was performed by the ANOVA test, followed by Bonferroni'correction. Both tests were performed using the software BioEstat 4.0 (Ayres et al. 2005).

\section{RESULTS}

The study showed in the -550 position the presence of alleles $M B L^{*} H$ and $M B L^{*} L$ with frequencies of $38 \%$ and $62 \%$ among HTLV-infected subjects and $38.5 \%$ and

\section{TABLE I}

Distribution of allele and genotype frequencies among HTLV infected subjects and controls

\begin{tabular}{ccccc}
\hline HTLV & Controls & $x^{2}$ & $\mathrm{p}$ \\
Polymorphism & infectedn $(\%)$ & $\mathrm{n}(\%)$ & &
\end{tabular}

\begin{tabular}{lcccc}
\hline Region -550 & & & & \\
H & $57(38)$ & $74(38.5)$ & - & - \\
L & $93(62)$ & $118(61.5)$ & - & - \\
Total & $150(100)$ & $192(100)$ & 0.000 & 0.9922 \\
HH & $14(19)$ & $14(15)$ & - & - \\
HL & $29(39)$ & $46(48)$ & - & - \\
LL & $32(42)$ & $36(37)$ & 1.533 & 0.4647 \\
Region -221 & & & & \\
X & $39(26)$ & $31(16.1)$ & - & - \\
Y & $111(64)$ & $161(83.9)$ & - & - \\
Total & $150(100)$ & $192(100)$ & 4.436 & 0.0352 \\
YY & $36(48)$ & $68(71)$ & - & - \\
YX & $39(52)$ & $25(26)$ & - & - \\
XX & $0(0)$ & $03(03)$ & 13.534 & 0.0012 \\
\hline
\end{tabular}

$\mathrm{n}=$ chromosomes sampled.
$61.5 \%$ among healthy controls, respectively. At the position -221 , the alleles $M B L^{*} X$ and $M B L^{*} Y$ showed frequencies of $26 \%$ and $64 \%$ among HTLV-infected subjects and $16.1 \%$ and $83.9 \%$ among healthy controls, respectively. The differences observed in the allele frequencies were not statistically significant for -550 position ( $p=0.992$; Table I), but the observed frequencies at the -221 region revealed a significant difference between the two groups $(p=0.035$; Table I).

The genotype differences between the two groups were statistically significant in the -221 position $\left(\chi^{2}=\right.$ 13.534; $\mathrm{p}=0.0012$; Table I). The highest level of significance was found in the frequencies of the genotypes YY and YX, which were 48\% and 52\% among HTLV-infected and $71 \%$ and $26 \%$ among controls.

The odds ratio estimation (OR) showed that the presence of $\mathrm{X}$ allele $(\mathrm{OR}=1.825 ; \mathrm{p}=0.035 ; 1.074 \leq \mathrm{IC} 95 \%$ $\leq 3.100$ ) was associated with an increased risk for HTLV infection. On the other hand, a low risk for HTLV infection was evidenced for those patients carrying the $\mathrm{Y}$ allele $(\mathrm{OR}=0.548 ; \mathrm{p}=0.035 ; 0.322 \leq \mathrm{IC} 95 \% \leq 0.931)$.

The differences in the observed haplotype frequencies were not statistically significant $\left(\chi^{2}=6.179 ; \mathrm{p}=\right.$ 0.103 ; Table II), but the genotype frequencies between

\section{TABLE II}

Distribution of haplotype frequencies among HTLV infected subjects and controls

\begin{tabular}{lcccc}
\hline Haplotypes & $\begin{array}{c}\text { HTLV } \\
\text { infected n }(\%)\end{array}$ & $\begin{array}{c}\text { Controls } \\
\mathrm{n}(\%)\end{array}$ & $x^{2}$ & $\mathrm{p}$ \\
\hline HY & $53(35.33)$ & $69(35.94)$ & - & - \\
LY & $58(386)$ & $92(47.92)$ & - & - \\
LX & $35(23.33)$ & $26(13.54)$ & - & - \\
HX & $04(2.66)$ & $05(2.60)$ & - & - \\
\hline Total & $150(100)$ & $192(100)$ & 6.179 & 0.103 \\
\hline
\end{tabular}

$\mathrm{n}=$ chromosomes sampled.

TABLE III

Distribution of genotype frequencies among HTLV infected subjects and controls

\begin{tabular}{lcccc}
\hline Genotype & $\begin{array}{c}\text { HTLV } \\
\text { infected } \mathrm{n}(\%)\end{array}$ & $\begin{array}{c}\text { Controls } \\
\mathrm{n}(\%)\end{array}$ & $x^{2}$ & $\mathrm{p}$ \\
\hline HYHY & $10(13.33)$ & $13(13.54)$ & - & - \\
HYLY & $13(17.33)$ & $30(31.25)$ & - & - \\
HYLX & $16(21.33)$ & $12(12.50)$ & - & - \\
HYHX & $04(5.33)$ & $01(1.04)$ & - & - \\
LYLY & $13(17.33)$ & $25(26.04)$ & - & - \\
LYLX & $19(25.33)$ & $09(9.38)$ & - & - \\
LYHX & $0(0)$ & $03(3.12)$ & - & - \\
LXLX & $0(0)$ & $02(2.09)$ & - & - \\
LXHX & $0(0)$ & $01(1.04)$ & - & - \\
\hline Total & $75(100)$ & $96(100)$ & 20.214 & 0.0096 \\
\hline $\mathrm{n}=$ number of investigated subjects.
\end{tabular}

$\mathrm{n}=$ number of investigated subjects. 
the two groups, revealed a higher prevalence of genotype LYLX (25.3\%), which has been associated with medium and low MBL serum levels, among HTLV-infected subjects $\left(\chi^{2}=20.214 ; p=0.0096\right.$; Table III). The odds ratio estimation demonstrated that the presence of genotype LYLX was associated with an increased risk of HTLV infection ( $\mathrm{p}=0.0096 ; 1.38 \leq \mathrm{IC} 95 \% \leq 7.7605)$. Additionally, when HTLV-1 and HTLV-2 infection were taken into account, no significant $\left(\chi^{2}=6.259 ; \mathrm{p}=0.282\right)$ difference of the genotype frequencies was observed.

The quantification of HTLV proviral load according to the presence of genotypes showed no association between the polymorphism in the promoter region with the levels of DNA proviral copies per $\mathrm{mm}^{3}(\mathrm{p}>0.05$; Table IV). However, when exon 1 polymorphism data, previously published (Pontes et al. 2005), were matched with those on the promoter region described herein (Table V), it was possible to identify a significant higher proviral load between HTLV infected individuals carrying haplotypes correlated to the low serum levels of MBL and those carrying haplotypes associated to high/medium MBL serum levels.

\section{DISCUSSION}

MBL is an important serum protein of the host's innate defense against microorganisms due to its ability to activate the complement system during the acute-phase of infection (Kilpatrick 2002), but several studies have shown that the presence of genetic polymorphisms of the promoter region of MBL gene, specially at the positions

TABLE IV

Quantification of the proviral load according to the MBL gene polymorphism

\begin{tabular}{lccc}
\hline Genotypes & $\mathrm{n}$ & $\begin{array}{c}\text { Proviral }^{\left(\operatorname{load}^{a}\right.} \\
\left(\text { copies } / \mathrm{mm}^{3} \text { ) }\right.\end{array}$ & $\log _{10}$ \\
\hline HYHY & 10 & 178.50 & 2.251 \\
HYLY & 13 & 282.54 & 2.451 \\
HYLX & 16 & 212.37 & 2.327 \\
HYHX & 3 & 64.67 & 1.810 \\
LYLY & 12 & 192.83 & 2.285 \\
LYLX & 19 & 202.10 & 2.305 \\
\hline
\end{tabular}

$\overline{\mathrm{n}}=$ number of investigated subjects. $a$ : proviral load and log values in arithmetic mean ( $\mathrm{p}$-values $>0.05)$.
-550 and -221 , affect the serum protein levels (Madsen et al. 1995, Steffensen et al. 2000, Lee et al. 2005) and, consequently, increase the susceptibility to infectious diseases (Madsen et al. 1995, Prohászka et al. 1997).

In the present study the allele and the haplotype frequencies in the promoter region of the MBL gene was described among HTLV-infected subjects and seronegative controls in order to investigate the possible role of the promoter polymorphism in face of an HTLV infection.

At the -550 region there were no significant differences in the allele and haplotype frequencies in both HTLV-infected and controls. On the other hand, at the -221 region it was observed a significant difference due to the higher prevalence of the allele $\mathrm{X}$ and the YX haplotype among HTLV-infected. Additionally, there was an increased risk for HTLV infection in subjects carrying the allele $\mathrm{X}$ and the genotype LYLX. Regarding that previous studies which have reported that the two promoter polymorphism of $-550(\mathrm{H} / \mathrm{L})$ and $-221(\mathrm{X} / \mathrm{Y})$ are associated with low serum MBL levels and that the effect of -221 promoter polymorphism is stronger than -550 promoter polymorphism (Madsen et al. 1995, Steffensen et al. 2000) we could suggest that -550 promoter polymorphism has no influence on HTLV infection, but the -221 promoter polymorphism seems to be associated with HTLV infection.

The carbohydrate components existent in HTLV can be bond by the MBL oligomeric structure. Thus, it is possible that the polymorphism in the MBL gene, specially that present in the promoter region, can be associated with HTLV infection. As previously suggested the MBL can bind to the virus or infected cells followed by the activation of the complement systems (Garred et al. 2003). Thus the low MBL plasma concentration, and subsequent reduction of the complement activation, could contribute to an increased susceptibility to HTLV infection. Recently, we have demonstrated a high association between coding variant at codon 54 of MBL gene with the susceptibility to HTLV infection (Pontes et al. 2005).

When HTLV-1 and HTLV-2 infections were considered separately, no significant difference of the genotype frequencies was observed between the groups. It is in disaccording with our previous study that identified significant differences for exon 1 polymorphism, even regarding that the previous result could be attributed to the number of investigated HTLV-1-infected subjects being higher than that of HTLV-2-infected individuals (Pontes et al. 2005).

TABLE V

Quantification of the proviral load according to the MBL genotypes associated with MBL serum levels

\begin{tabular}{|c|c|c|c|c|c|}
\hline Genotypes & MBL Level $^{a}$ & $\mathrm{n}$ & $\begin{array}{l}\text { Proviral load } \\
\left(\text { copies } / \mathrm{mm}^{3} \text { ) }\right.\end{array}$ & $\log _{10}$ & $\mathrm{p}$ \\
\hline HYA/A, HY/LYA, LYA/A, LY/LXA, HYO/O, HYA/LYO, HYA/LXO & High and Medium & 50 & 143.9 & 2.15 & \\
\hline LYA/O, LYO/O, LYO/LXA, HY/LXO, LY/LXO & Low & 23 & 357.9 & 2.55 & $<0.05$ \\
\hline
\end{tabular}

$\mathrm{n}=$ number of investigated subjects. $a$ : Garred et al (2003); $b$ : proviral load and log values in arithmetic mean. 
The differences observed in the allele and haplotype frequencies obtained in the present study and those reported for Caucasians, Japaneses, Africans, Koreans and Eskimos (Madsen et al. 1995, Matsushita et al. 1998, Steffensen et al. 2000, Lee et al. 2005) could be attributed to the differences of genetic background among ethnic groups. The genetic contribution of the populations inhabiting the Brazilian Amazon region indicates a clear trihybrid model in which the contribution of Whites, Indians and Blacks has been estimated about 47, 41 and 12\%, respectively (Santos \& Guerreiro 1995).

Nishimura et al. (2003) showed the association between the presence of allele MBL*B and low levels of HTLV proviral load, but our previous results suggest that the presence of the coding variant at codon 54 might contribute to an inefficient elimination of the virus and a consequent increase of proviral load (Pontes et al. 2005). We were not able to identify, in the present study, any association between -221 and -550 promoter polymorphisms with the high or low values of proviral load which suggest absence of influence of the promoter polymorphisms. But when matching the polymorphisms results of the promoter and exon 1 regions, identified a significant association between high proviral load and the presence of genotypes correlated to low MBL serum levels, highlighting our previous report showing the direct influence of the structural mutation on exon 1 regarding HTLV proviral load. Thus, the results obtained suggest that the low serum levels of MBL could contribute to an inefficient elimination of the virus and a consequent increase of proviral load.

The results of the present study suggest an association between promoter polymorphism of the MBL gene and HTLV infection. Additionally, it is also important to pursue the possibility of whether the MBL gene polymorphism could have any impact on the diseases associated with HTLV infection.

\section{ACKOWLEDGEMENTS}

To all subjects involved in this study.

\section{REFERENCES}

Ayres M, Ayres JR, M Ayres DL, Santos AS 2005. BioEstat 4.0: Aplicações estatísticas nas áreas das ciências biológicas e médicas. Sociedade Civil Mamirauá/MCT-CNPq/Conservation International, Belém, 323 pp.

Garred P, Larsen F, Madsen HO, Koch C 2003. Mannose-binding lectin deficiency - revised. Mol Immunol 40: 73-84.

Gessain A, Barin F, Vernant JC, Gout O, Maurs L, Calender A, De Thé G 1985. Antibodies to human T-lymphotropic virus type I in patients with tropical spastic paraparesis. Lancet 2: 407-410.

Hall WW, Kubo T, Ijichi S, Takahashi H, Zhu SW 1994. Human Tcell leukemia virus type II (HTLV-II): emergence of a newly recognized pathogen. Semin Virol 5: 168-178.

Jüliger S, Luckner D, Mordmüller B, May J, Weierich A, Lell B, Luty A, Kremsner PG, Kun FJJ 2000. Promoter variants of the human mannose-binding lectin gene show different binding. Biochem Biophys Res Commun 275: 617-622.
Kilpatrick DC 2002. Mannan-binding lectin and its role in innate immunity. Transfus Med 12:335-351.

Lee SG, Yum JS, Moon HM, Kim HJ, Yang YJ, Kim HJ, Yoom Y, Lee S, Song K 2005. Analysis of mannose-binding lectin 2 (MBL2) genotype and the serum protein levels in the Korean population. Mol Immunol 42: 969-977.

Madsen HO, Garred P, Thiel S, Kurtzhals JAL, Lamm LU, Ryder LP, Svejgaard A 1995. Interplay between promoter and strutural gene variants control basal serum level of Mannan-Biding Protein. J Immunol 155: 3013-3020.

Matsushita M, Hijikata M, Matsushita M, Ohta Y, Mishiro S 1998. Association of mannose-binding lectin gene haplotype LXPA and LYPB with interferon-resistant hepatitis $\mathrm{C}$ virus infection in Japanese patients. J Hepatol 29: 695-700.

Nishimura M, Maeda M, Matsuoka M, Mine H, Saji H, Matsui M, Kuroda Y, Kawakami H, Uchiyama U 2000. Tumor necrosis factor, tumor necrosis factor receptors type 1 and 2, lymphotoxin $-\alpha$ and HLA-DRB1 gene polimorphisms in human T-cell lymphotropic virus type I associated myelopathy. Hum Immunol 61: 1262-1272.

Nishimura M, Maeda M, Yasunaga J, Kawakami H, Kaji R, Adachi A, Uchiyama T, Matsuoka M 2003. Influence of cytokine and mannose binding protein gene polymorphism on human T-cell leukemia virus type I (HTLV-I) provirus load in HTLV-I asymptomatic carriers. Hum Immunol 64: 453-457.

Nitta T, Tanaka M, Sun B, Hanai S, Miwa M 2003. The genetic background as a determinant of human T-cell leukemia virus type 1 proviral load. Biochem Biophys Res Commun 309: 161-165.

Osame M, Usuku K, Isumo, Ijichi N, Amitani H, Igata A, Matsumoto M, Tara M 1986. Human T-cell Leukaemia/lymphoma Virus type I associated myelopathy, a new clinical entity. Lancet 1: 1031-1032.

Pontes GS, Tamegão-Lopes B, Machado LFA, Azevedo VN, Ishak MOG, Ishak R, Lemos JAR, Vallinoto ACR 2005. Characterization of mannose-binding lectin gene polymorphism among human T-cell lymphotropic virus 1 and 2 -infected asymptomatic subjects. Hum Immunol 66: 892-896.

Prohászka Z, Thiel S, Ujhelyi E, Szlávik J, Banhegyi D, Füst G 1997. Mannan-binding lectin serum concentrations in HIVinfected patients are influenced by the stage of disease. Immunol Lett 58: 171-175.

Santos SEB, Guerreiro JF 1995. The indigenous contribution to the formation of the population of the Brazilian Amazon Region. Rev Bras Gen 18: 311-315.

Steffensen R, Thiel S, Varming K, Jersild C, Jensenius JC 2000. Detection of structural gene mutations and promoter polymorphisms in the mannan-binding lectin (MBL) gene by polymerase chain reaction with sequence-specific primers. $J$ Immunol Methods 241: 33-42.

Tamegão-Lopes BP, Rezende PR, Maradei-Pereira LMC, Lemos JAR 2006. HTLV-1 and HTLV-2 proviral load: a simple method by quantitative Real Time PCR. Rev Soc Bras Med Trop 39: 548-552.

Turner MW 2003. The role of mannose-binding lectin in health and disease. Mol Immnunol 40: 423-429. 